21. Девятова Е.В. Исследования малакофауны озера, испытывающего влияние медеплавильного производства // Актуальные вопросы экологии и природопользования: сборник трудов всерос. науч.-практ. конф., посв. памяти члена-корреспондента АН РБ, доктора биологических наук, профессора Миркина
Бориса Михайловича. Ч. 1 / отв. ред. С.А. Башкатов. Уфа: РИЦ БашГУ, 2017. С. 112-114.

Работа выполнена при финансовой поддержске сетевого гранта с Мордовским государственным педагогическим университетом 14-05/2019 от 04.06.2019.

\title{
ACCUMULATION OF HEAVY METALS BY FAMILY LYMNAEIDAE REPRESENTATIVES AS RESPONSE TO ANTHROPOGENIC POLLUTION CRITICAL LEVELS OF SOUTH URAL RESERVOIRS
}

(C) 2019

\author{
Deryagin Vladimir Vladislavovich, candidate of geographical sciences, \\ associate professor of Geography and Geography Methodology Department \\ Nazarenko Nazar Nikolayevich, doctor of biological sciences, \\ professor of Chemistry, Ecology and Chemistry Methodology Department \\ Devyatova Ekaterina Viktorovna, student of Natural Sciences and Technologies Faculty \\ South Ural State Humanitarian Pedagogical University (Chelyabinsk, Russian Federation)
}

\begin{abstract}
The features of heavy metals accumulation by Lymnaea fragilis and L. psilia were researched for the aerate emission polluted area of Karabash copper-smelting manufacturing (Southern Ural). These features are concluded with selective redistribution of heavy metals between soft tissues and the shell of Lymnaea. The heavy metals accumulation takes place by three independent tendencies: «water $\rightarrow$ soft tissues», «water $\rightarrow$ shell» and «soft tissues $\rightarrow$ shell». The heavy metals content levels a thousand times exceed the physiological norm in soft tissues while in shell they exceed manifold. In the first place manganese and iron are accumulated while the cobalt, cadmium and molybdenum are finalizing the researched rank of accumulation. It has been ascertained that more biophil manganese are accumulated in mollusk soft tissues more than in other metals, while slightly less biophil iron is accumulated in shell, mainly in surface layers. For soft tissues and shell different ranks of heavy metals accumulation are observed, but these ranks are similar for different habitats, thus qualitative biogeochemical similarity is observed. The heavy metals accumulation in the system «water $\rightarrow$ soft tissues $\rightarrow$ shell» can help to estimate the extent of the metal environment pollution as well as local biophility of this metal. The adaptive response of pond snails to anthropogenic pollution is that there are more of them in less polluted reservoirs and less in more polluted reservoirs. It has been confirmed, that high heavy metals concentration and low $\mathrm{pH}$ level in reservoirs leads to death and absolute absence of these mollusk species.

Keywords: family Lymnaeidae; biological indicators; pollution accumulation by hydrobionts; pollution concentration and de-concentration by hydrobionts; heavy metals; adaptive answering; pollution of copper-smelting industry; aerate emissions; anthropogenic pollution; Southern Ural.
\end{abstract}

$* * *$

\section{ИСПОЛЬЗОВАНИЕ ГНЁЗД ВРАНОВЫХ ДРУГИМИ ВИДАМИ ПТИЦ В БАЙКАЛЬСКОЙ СИБИРИ И МОНГОЛИИ}

(C) 2019

Доржиев Цыдыпжап Заятуевич, доктор биологических наук, профессор кафедры зоологии и экологии

Бадмаева Евгения Николаевна, кандидат биологических наук, доцент кафедры зоологии и экологии Даянжав Цогтбаатар, аспирант кафедры зоологии и экологии

Энхсайхан Ууганбаяр, аспирант кафедры зоологии и экологии

Бурятский государственный университет им. Доржи Банзарова (г. Улан-Удэ, Российская Федераџия)

Саая Арияна Томур-ооловна, аспирант кафедры зоологии и экологии; младший научный сотрудник лаборатории естественных наук

Бурятский государственньй университет им. Доржи Банзарова (г. Улан-Удэ, Российская Федеращия); Тувинский научный цеентр (2. Кызыл, Российская Федераџия)

\footnotetext{
Аннотащия. В статье приводится видовой состав птиц-квартирантов врановых в Байкальской Сибири и Монголии. Обследовано более 700 гнезд восьми видов врановых птиц в Забайкалье, Прибайкалье и Монголии. Отмечено 133 случая использования гнезд пяти видов врановых (сороки, восточной черной вороны, ворона, грача и даурской галки) другими видами птиц. Гнезда мелких врановых не привлекают других птиц. Наиболее часто используются гнезда сорок, которые отличаются специфическим строением. Из восьми видов, использующих сооружения врановых для гнездования, амурский кобчик и ушастая сова являются облигатными квартирантами. Ближе к ним стоит пустельга, которая из всех гнездовых укрытий предпочитает гнезда сорок. Численность этих видов во многих местах определяется обилием сорок и ворон. В последние
} 
ы, благодаря высокой численности сорок, количество амурских кобчиков в регионе растет. Они начали вслед за сороками проникать на окраины г. Улан-Удэ. Три вида (кряква, чеглок, полевой воробьи) отнесены к факультативным квартирантам и еще три вида (огарь, длиннохвостая неясыть и домовый воробей) - к случайным. Из них в естественных биотопах часто гнездятся в гнездах сорок полевые воробьи. Почти все виды квартирантов используют старые гнезда хозяев. Выявлено региональные особенности в использовании гнезд врановых. Некоторые виды в разных регионах отдают не одинаковое предпочтение сооружениям разных видов врановых.

Ключевые слова: гнездовые взаимоотношения; облигатное квартиранство; факультативное квартиранство; численность; гнезда врановых; сорока; черная ворона; ворон; грач; даурская галка; огарь; кряква; пустельга; чеглок; амурский кобчик; длиннохвостая неясыть; ушастая сова; домовый воробей; полевой воробей; Забайкалье; Прибайкалье; Монголия.

\section{Введение}

Гнезда врановых, как известно, используют для выведения птенцов многие другие виды птиц [1-7]. В отдельных районах ареалов птицы-квартиранты ведут себя несколько по-разному, в частности, в предпочтительном использовании гнезд разных видов врановых. Для облигатных видов-квартирантов наличие гнезд врановых и их численность имеет, несомненно, большое значение. От них может зависеть состояние их популяций.

В Сибири и Центральной Азии сведений подобного рода немного [8-10]. Специальных исследования по гнездовым взаимоотношениям разных видов птиц не было проведено.

Цель данной работы - выявление видового состава птиц-квартирантов врановых в Байкальской Сибири и Монголии.

\section{Материал и методика}

В течение более 40 лет (с 1973 г.) нами планомерно исследуются птицы на территории двух смежных регионов - Монголии и Байкальской Сибири (бассейн оз. Байкал в пределах России, куда входит часть Западного Забайкалья и Прибайкалье). Отрывочные наблюдения проводились и раньше. В течение нескольких лет целенаправленно изучали здесь экологию врановых птиц [11]. Осмотрено более 700 гнезд 8 видов врановых: сойка Garrulus glandarius L., голубая сорока Cyanopica cyanus Pall., сорока, Pica pica L., клушица Pyrrhocorax pyrrhocorax L., даурская галка Corvus dauuricus Pall., грач Corvus frugilegus L., восточная черная ворона Corvus orientalis Ever. и ворон Corvus corax L. Из них большинство гнезд принадлежит грачу, восточной черной вороне и сороке. В период исследований врановых, а также хищных птиц нами зарегистрированы все случаи ис- пользования гнезд врановых другими видами. Отмечено всего 133 случая использования видами-квартирантами гнезд 5 видов врановых.

\section{Результаты и обсуждение}

В Монголии и Забайкалье отмечено нами гнездование 8 видов птиц в гнездах врановых, а также зарегистрировано поочередное использование одного гнездового укрытия (дупла) даурской галкой и огарем (табл. 1).

Огарь гнездится в различных укрытиях, в том числе иногда в широких дуплах деревьев среди островных разреженных лесов в открытых ландшафтах региона. В Забайкалье чаще устраивает гнезда в нишах скал и останцов среди степей, в Монголии кроме того довольно часто использует старые норы монгольских сурков.

В долине р. Гарги (левый приток р. Баргузина, Восточное Прибайкалье) в тополевниках с большими дуплами регулярно гнездятся даурские галки. В одном и том же дупле тополя мы два раза отмечали гнездование огаря, где до этого ежегодно выводили птенцов галки. В данном случае речь идет об использовании огарем и даурской галкой одного и того же укрытия для гнездования, но данный случай не относится к квартиранству огаря у даурской галки.

Кряква обычно устраивает гнездо на земле вблизи водоемов. Отмечено нами два случая гнездования данной утки в старых, но с сохранившимися крышами гнездах сороки: в долине р. Баргузина (24.05.1993) и окр. г. Улан-Удэ (16.05.1999). Гнезда располагались на ивах на берегу рек на высоте 2,02,5 м. С обоих гнезд мы вспугнули насиживающих самок. Во втором случае нами была прослежена судьба кладки. Самке удалось успешно завершить насиживание, 2 июня пуховички покинули гнездо сороки.

Таблица 1 - Использование гнезд врановых другими видами птиц в Байкальской Сибири и Монголии

\begin{tabular}{|c|c|c|c|c|c|c|}
\hline \multirow{2}{*}{$\begin{array}{l}\text { Виды птиц, гнездящиеся } \\
\text { в гнездах врановых }\end{array}$} & \multirow{2}{*}{$\begin{array}{c}\text { Число случаев } \\
\text { использования } \\
\text { гнезд врановых }\end{array}$} & \multicolumn{5}{|c|}{$\begin{array}{c}\text { Число гнезд квартирантов, } \\
\text { зарегистрированных в гнездах врановых птиц }\end{array}$} \\
\hline & & сорока & $\begin{array}{l}\text { черная } \\
\text { ворона }\end{array}$ & ворон & грач & $\begin{array}{c}\text { даурская } \\
\text { галка }\end{array}$ \\
\hline Огарь Tadorna ferruginea & 2 & & & & & $2 ?$ \\
\hline Кряква Anas platyrhynchos & 2 & 2 & & & & \\
\hline Пустельга Falco tinnunculus & 45 & 40 & 5 & & & \\
\hline Амурский кобчик Falco amurensis & 16 & 15 & 1 & & & \\
\hline Чеглок Falco subbuteo & 9 & & 9 & & & \\
\hline Длиннохвостая неясыть Strix uralensis & 1 & 1 & & & & \\
\hline Ушастая сова Asio otus & 9 & 7 & 1 & & 1 & \\
\hline Домовый воробей Passer domesticus & 1 & 1 & & & & \\
\hline Полевой воробей Passer montanus & 53 & 51 & & 2 & & \\
\hline
\end{tabular}


Пустельга. Этот вид наряду с другими гнездовыми укрытиями довольно часто использует гнезда врановых птиц в пределах всего ареала [12;13] и др. Во время исследований врановых мы обнаружили очень много случаев использования старых гнезд сорок этим соколом, реже они гнездились в сооружениях восточных черных ворон (табл. 1). По приблизительным данным, в Байкальской Сибири около одной третьи гнезд эти соколы размещают в скалах, реже в постройках человека, остальные в сооружениях врановых. Причем в разных местах предпочтительное отношение к тем или иным укрытиям различается, зависит от их наличия. В поймах рек, на окраинах лесов они, как правило, выбирают сорочьи или вороньи гнезда, в степи - скалы. В городах Улан-Удэ и Улан-Батор даже при наличии гнезд врановых предпочитают укрытия в постройках человека.

По нашим наблюдениям, в пойме р. Селенги и ее протоков в окр. г. Улан-Удэ, где достаточно много старых и новых гнезд сорок и восточных черных ворон, соколы выбирали старые гнезда сорок. Причем все гнезда, занятые ими, были полуразрушены сбоку, но имели крышу. Гнезда сорок без крыши они не занимали. Не отмечено нами случаев использования свежих гнезд врановых, хотя в литературе из других регионов есть сведения об отбирании гнезд у ворон и сорок $[14 ; 15]$. Отмечен интересный случай гнездования по соседству пустельги, сороки и ушастой совы в пойме р. Селенги [9]. Гнезда первых двух видов располагались на иве в одном большом сооружении, представляющем собой двухэтажное гнездо сороки. Внизу (старое гнездо сороки) устроилась пустельга, а наверху - пара сорок в своем новом гнезде. На соседней иве в 3 м от них в старом гнезде сороки насиживала кладку ушастая сова. Никаких агрессивных взаимоотношений между ними при осмотре гнезд не наблюдалось.

Амурский кобчик. Этот вид исключительно связан в гнездовое время с сороками, чьи сооружения являются основными укрытиями для выведения птенцов $[8 ; 16 ; 9 ; 17]$. Есть лишь упоминание об использовании гнезда восточной черной вороны в Восточном Забайкалье [10]. Амурские кобчики используют исключительно старые гнезда сорок. Все гнезда, занятые ими, имели крышу, но с довольно хорошо открытой боковой стороной. В последние годы численность кобчиков растет в регионе. Они начали вслед за сороками проникать на окраины г. УланУдэ. Уже есть факты гнездования их в сорочьих гнездах в вобранных сосновых лесах в новых кварталах города недалеко от жилых построек. При этом они охотятся в открытых биотопах в окрестностях города. Пока это единичные случаи гнездования их в населенных пунктах.

Чеглок. Все 9 найденных гнезд располагались в гнездах восточных черных ворон на довольно высоких соснах в верхней части кроны вблизи широких речных пойм, озер, полей и степей [9]. Сорочьи гнезда они игнорировали, хотя в Средней Азии и Казахстане они чаще используют их [18; 19].

Длиннохвостая неясыть. Одно гнездо данного вида нами было найдено 12 июня 1978 г. в старом гнезде сороки на иве на окраине соснового леса в местности Добо-Енхор (северный макросклон хр. УланБургасы) в 50 км от г. Улан-Удэ. В гнезде было
3 птенца. В Предбайкалье, соседнем регионе, найдено гнездо неясыти в сооружении восточной черной вороны [20]. Пожалуй, эти редкие случаи использования длиннохвостой неясытью гнезд врановых птиц. Обычно этот вид гнездится в дуплах, но при дефиците крупных дуплистых деревьев, по-видимому, вынужден использовать другие укрытия. Гнездование длиннохвостой неясыти в гнездах других птиц, но не врановых, известно в Европе и на Дальнем Востоке [21;22].

Ушастая сова. Использование чужих гнезд для ушастой совы обычное явление $[23 ; 21 ; 12 ; 24 ; 5]$. Нами найдено 9 гнезд ушастой совы. Все они были размещены в гнездах трех видов врановых: сороки 7 гнезд, восточной черной вороны и грача - по одному. Из них 5 гнезд зарегистрированы в сорочьих гнездах в ивняках в пойме протоки р. Селенги в окр. г. Улан-Удэ, одно гнездо - на окраине соснового леса в дельте р. Селенги и еще одно гнездо - в березовой роще в окр. оз. Щучьего в Гусиноозерской котловине. Только одно гнездо находилось в гнезде грача на окраине грачиной колонии в березовой роще в окр. оз. Щучьего в Гусиноозерской котловине. Вероятно, сова заняла гнездо еще до появления хозяев на гнездовой колонии. В противном случае грачи не допустили бы ее к поселению. В этих же биотопах встречались гнезда восточных черных ворон, только в одном из них отмечено гнездование данной совы. В соседнем Восточном Саяне нами из 9 гнезд совы -6 обнаружили в гнезде сороки и 3 - восточной черной вороны [25]. Наиболее часто совы занимают полуразрушенные гнезда сорок с широким входом сбоку и полуоткрытой крышей. Их они не обустраивают. По наблюдениям А.В. Шарикова [6], иногда они частично разбирают крышу. В наших наблюдениях не было случаев гнездования сов в свежих гнездах врановых, в других регионах есть случаи захвата ими свежих гнезд врановых [1].

Ушастые совы в окр. г. Улан-Удэ в пойме р. Селенги и в березовой роще в окр. оз. Щучье при наличии в достаточном количестве старых гнезд врановых явно выбирали сооружения сорок, игнорируя гнезда ворон и грачей. При этом совы предпочитали окраинные участки или поляны среди ивняков или березовой рощи. Лишь одно гнездо располагалось на одиночной иве среди степного участка недалеко от поймы. Выбор участков на опушках леса и лесных полян связан с предпочтительной охотой сов в открытых местах, в глубине леса они охотятся редко.

Домовый воробей. В исследуемом регионе этот вид является облигатной синантропной птицей, в естественных биотопах не гнездится. Единственный случай гнездования данного вида в гнезде сороки отмечено в с. Дарьганга (Сухэ-Баторский аймак, юго-восточная Монголия) в июле 2015 г. Взрослые птицы кормили гнездовых птенцов. В Байкальской Сибири мы ни разу не отмечали использование этими воробьями гнезд врановых в населенных пунктах, где они не испытывают дефицита удобных укрытий для гнездования в постройках человека.

Полевой воробей. Как известно, данный вид довольно пластичен в выборе укрытий для гнездования как естественных, так и антропогенных ландшафтах. В исследуемом нами регионе полевой воробей также гнездится в разнообразных убежищах [26; 27]. 
Известно использование полевыми воробьями в разных частях ареала гнезд почти 30 других видов птиц [28]. В естественных биотопах Монголии и Байкальской Сибири нами зарегистрированы гнезда полевых воробьев в сооружениях хищных птиц (черного коршуна Milvus migrans, мохноногого курганника Buteo hemilasius, степного орла Aquila nipalensis, орла-могильника Aquila heliaca, беркута Aquila chrysaetos), серой цапли Ardea cinerea, береговушки Riparia riparia, деревенской ласточки Hirundo rusti$c a$, воронка Delichon urbicum, в Восточном Забайкалье - кроме того, мы находили гнездовых птенцов в жилом гнезде черного аиста Ciconia nigra. Более часто здесь эти воробьи используют сооружения врановых птиц, а именно сороки. Так, в пойме р. Селенги в окр. г. Улан-Удэ и по берегам р. Туул в окр. г. Улан-Батор почти в каждом четвертом-пятом гнезде сороки в ивняках можно обнаружить воробьев. Они используют как старые, но массивные, так и жилые гнезда сорок. В жилых сооружениях воробьи обычно устраивают гнезда в нижней части сооружения, если она рыхлая. В старых гнездах сорок, если боковые стенки их сильно не разрушены, воробьи иногда забивают строительным материалом весь лоток, а при неоднократном использовании - более половины внутренней полости сооружения. В населенных пунктах полевые воробьи практически не поселяются в гнездах врановых. По крайней мере, мы их не находили. В сооружениях других врановых полевые воробьи гнездятся очень редко. Нами зарегистрировано гнездование полевого воробья в одном и том же жилом гнезде ворона два года подряд в окр. г. Улан-Удэ в пойме р. Селенги.

\section{Заключение}

Гнезда отдельных врановых птиц являются для многих других видов удобными укрытиями для гнездования, особенно гнезда сорок, имеющие специфическое строение. Гнезда мелких врановых не привлекают для гнездования другие виды птиц. Такие виды, как амурский кобчик, пустельга, ушастая сова, наиболее тесно связаны в регионе с врановыми, и их численность во многих местах связана с их обилием. У амурского кобчика, возможно, и ушастой совы установились гнездовые взаимоотношения с врановыми в виде облигатного квартиранства. Близка к облигатному квартиранству с врановыми пустельга. Большинство остальных видов является у врановых факультативными квартирантами, а огарь и длиннохвостая неясыть и домовый воробей - случайными. В пределах ареала многие из указанных видов используют гнезда врановых, но в разных его частях предпочтения гнезд тех или иных видов врановых имеют некоторые региональные особенности.

\section{Список литературы:}

1. Константинов В.М., Бабенко В.Г., Барышева И.К. Численность и некоторые черты экологии синантропных популяций врановых птиц в условиях интенсивной урбанизации // Зоологический журнал. 1982. T. LXI, вып. 12. С. 1837-1845.

2. Константинов В.М., Родимцев А.С., Пономарев В.А., Климов С.М., Марголин В.А., Лебедев И.Г. Сорока (Pica pica L.) в антропогенных ландшафтах Палеарктики (проблемы синантропизации и урбанизации). М.: Прометей, 2004. 160 с.
3. Абуладзе А.В. Некоторые аспекты взаимоотношений соколообразных и врановых в Восточной Грузии // Врановые птицы в естественных и антропогенных ландшафтах: мат-лы II всесоюз. совещ. Ч. 1. Липецк: Липецкий пединститут, 1989. С. 43-46.

4. Музаев В.М., Кукиш А.И., Эрдненов Г.И. Использование гнезд врановых другими видами птиц в Калмыкии // Русский орнитологический журнал. 2003. Экспресс-выпуск 214. С. 247.

5. Ильюх М.П., Хохлов А.Н. Хищные птицы и совы трансформированных экосистем Предкавказья. Ставрополь: Изд-во СевКавГТУ, 2010. 760 с.

6. Шариков А.В. Особенности взаимоотношений ушастой совы Asio otus и врановых птиц в гнездовой период // Русский орнитологический журнал. 2012. Т. 21, экспресс-выпуск 789. С. 2085-2087.

7. Шаповал А.П. Материалы по гнездованию ушастой совы Asio otus в окрестностях села Лазорки (запад Полтавской области) // Русский орнитологический журнал. 2013. Т. 22, экспресс-выпуск 843. C. $288-290$.

8. Шагдарсурэн О. К экологии амурского кобчика в Монгольской Народной Республике // Орнитология. 1965. Вып. 7. С. 350-352.

9. Доржиев Ц.З. Симпатрия и сравнительная экология близких видов птиц (бассейн озера Байкал). Улан-Удэ: Изд-во Бурятского университета, 1997. $370 \mathrm{c}$.

10. Щекин Б.В. Птицы Даурии. Чита: Забайкал. гос. гум. пед. ун-т, 2007. 504 с.

11. Доржиев Ц.3., Ешеев В.Е. Сравнительная экология симпатрических видов врановых рода Corvus юга Сибири // Орнитологические исследования в России. М.-Улан-Удэ: Изд-во Бурятского университета, 1997. С. 72-93.

12. Шепель А.И. Хищные птицы и совы Пермского Прикамья. Иркутск: Изд-во Иркут. ун-та, 1992. $296 \mathrm{c}$.

13. Бабенко В.Г. Птицы Нижнего Приамурья. М.: Изд-во Прометей, 2000. 726 с.

14. Полякова А.Д., Радецкий В.Р. К биологии обыкновенной пустельги в Тамбовской области // Орнитология. 1974. Вып. 11. С. 403-404.

15. Климов С.М. Материалы по фауне и экологии хищных птиц Липецкой области // Экология хищных птиц: мат-лы 1-го совещания по экологии и охране хищных птиц. М.: Изд-во МГПИ, 1983. С. 162-163.

16. Щекин Б.В. Гнездовая колония амурских кобчиков в лесостепи Забайкалья // Орнитология. 1965. Вып. 7. С. 153-156.

17. Доржиев Ц.З. Экология амурского кобчика в Западном Забайкалье // Современное состояние и проблемы охраны хищных птиц Восточной Евразии: мат-лы междунар. конф. М.: Изд-во МГПУ, 2008. C. $33-35$.

18. Ковшарь А.Ф. Птицы Таласского Алатау. Алма-Ата: Изд-во АН КазССР, 1966. 436 с.

19. Абдусалямов И.А. Фауна Таджикской ССР. Т. 19. Птицы. Ч. 1. Душанбе: Изд-во АН Тадж. ССР, $1971.403 \mathrm{c}$.

20. Малеев В.Г., Попов В.В. Птицы лесостепей Верхнего Приангарья. Иркутск: Изд-во «Время странствий», 2007. 300 с.

21. Мальчевский А.С., Пукинский Ю.Б. Птицы Ленинградской области и сопредельных территорий. 
Т. 1. Л.: Изд-во Ленинградского университета, 1983. $480 \mathrm{c}$.

22. Волковская-Курдюкова Е.А., Курдюков А.Б. Материалы по экологии и населению сов Приханкайской низменности // Русский орнитологический журнал. 2010. Т. 19, экспресс-выпуск 595. С. 1591-1612.

23. Кулаева Т.М. Отряд Совообразные Strigiformes // Птицы Волжско-Камского края. М.: Наука, 1977. C. 239-257.

24. Коровин В.А. Птицы в агроландшафтах Урала. Екатеринбург: Изд-во Уральского университета, 2004. $504 \mathrm{c}$.

25. Доржиев Ц.З., Дурнев Ю.А., Сонина М.В., Елаев Э.Н. Птицы Восточного Саяна. Улан-Удэ: Изд-во Бурятского ун-та, 2019. 400 с.
26. Доржиев Ц.З., Доржиева В.Д. К биологии размножения полевого воробья в Западном Забайкалье // Влияние антропогенных факторов на структуру и функционирование биоценозов. М.: Изд-во МГПИ, 1983. С. $78-88$.

27. Доржиев Ц.З., Доржиева В.Д. Особенности гнездования полевого воробья в населенных пунктах Забайкалья // Фауна и экология наземных позвоночных животных на территориях с разной степенью антропогенного воздействия. М.: Изд-во МГПИ, 1985. C. 21-34.

28. Полевой воробей Passer montanus L. (Характеристика вида на пространстве ареала) / под ред. Г.А. Носкова. Л.: Изд-во Ленинградского университета, 1981. $304 \mathrm{c}$.

\section{USE OF CORVIDS' NESTS BY OTHER BIRD SPECIES IN BAIKAL SIBERIA AND MONGOLIA} (C) 2019

Dorzhiev Tsydypzhap Zayatuevich, doctor of biological sciences, professor of Zoology and Ecology Department Badmaeva Evgeniya Nikolaevna, candidate of biological sciences, associate professor of Zoology and Ecology Department

Dayanzhav Tsogtbaatar, postgraduate student of Zoology and Ecology Department

Enkhsaikhan Uuganbayar, postgraduate student of Zoology and Ecology Department Buryat State University named after D. Banzarov (Ulan-Ude, Russian Federation)

Saaya Ariyana Tomur-oolovna, postgraduate student of Zoology and Ecology Department; junior researcher of Natural Sciences Laboratory

Buryat State University named after D. Banzarov (Ulan-Ude, Russian Federation); Tuvan Scientific Center (Kyzyl, Russian Federation)

Abstract. The paper presents the species composition of corvids in Baikal Siberia and Mongolia. More than 700 nests of 8 species of corvids in Transbaikalia, Baikal and Mongolia were examined. 133 cases of using nests of 5 species of corvids (Magpies, Eastern Carrion Crow, Rooks and Daurian Jackdaws) by other species of birds were noted. Nests of small corvids do not attract other birds. Nests of magpies are most commonly used; they are characterized by a specific structure. Of the 8 species that use corvid nests for nesting, Amur red-footed Falcon and longeared owl are obligate tenants. Then goes Kestrel that prefers magpie nests. The number of these types in many places is determined by the abundance of magpies and crows. In recent years, due to the high number of magpies, the number of Amur falcons in the region is growing. They began following magpies to penetrate the outskirts of UlanUde. Three species (Mallard, hobby, tree sparrows) are considered optional to be the tenants and three other species (Ruddy Shelduck, Long-eared Owl and House Sparrow) are considered to be random. Tree sparrows often nest in the magpie nests in natural habitats. Almost all types of tenants use old nests of the owners. Regional features in the use of corvid nests are revealed. Some species in different regions do not prefer the same nests of different types of corvids.

Keywords: nested relations; obligatory tenant; optional tenant; number; nests of corvids; Common Magpie; Eastern Carrion Crow; Raven; Rook; Daurian Jackdaw; Ruddy Shelduck; Mallard; Kestrel; Hobby; Amur Falcon; Ural Owl; Long-eared Owl; House Sparrow; Tree Sparrow; Transbaikalia; Baikal; Mongolia.

$* * *$

\section{ВЛИЯНИЕ ФЕНОЛОГИЧЕСКИХ ФАКТОРОВ НА МОРФОМЕТРИЧЕСКИЕ ПАРАМЕТРЫ СОЦВЕТИЙ РОДА CRATAEGUS L. В УСЛОВИЯХ КОЛЬСКОЙ СУБАРКТИКИ}

(C) 2019

Зотова Олеся Евгеньевна, младший научный сотрудник

лаборатории интродукции и акклиматизации растений

Гончарова Оксана Александровна, кандидат биологических наук, старший научный сотрудник лаборатории интродукции и акклиматизации растений

Полярно-альпийский ботанический сад-институт им. Н.А. Аврорина Кольского научного иентра РАН (2. Апатиты, Мурманская область, Российская Федерация)

Аннотация. В данной работе представлен материал о фенологическом развитии семи интродуцированных видах рода Crataegus L. в условиях Кольского Севера. Изученные виды боярышника характеризуются ранним началом вегетации, короткой длительностью линейного роста побегов и коротким периодом вегетации. 